\title{
KHIDHIR DALAM PANDANGAN IBN TAIMIYYAH
}

\author{
Shidqy Munjin \\ Universitas Islam Negeri Sunan Gunung Djati \\ Email: shidqymunjin@gmail.com
}

\begin{abstract}
Abstrak
Pemikiran Ibn Taimiyyah merupakan salah satu rujukan terpenting dalam dunia pemikiran Islam. Dua fatwa mengenai status keabadian Khidhir yang disandarkan kepada Ibn Taimiyyah menunjukkan atas hal itu. Penelitian ini mecoba mengungkap kedua jenis fatwa tersebut dan membandingkannya dengan pemikiran-pemikiran Ibn Taimiyyah secara umum. Penelitian ini menunjukkan bahwa keyakinan mengenai hidup atau wafatnya Khidhir merupakan keyakinan yang berlandaskan pada sumber yang sah.
\end{abstract}

Kata kunci: Ibn Taimiyyah, Khidhir.

\begin{abstract}
Ibn Taimiyyah's thinking is one of the most important references in the world of Islamic thought. Two fatwas concerning the status of Khidhir's immortality based on Ibn Taimiyyah show that. This research attempts to uncover both types of fatwas and compare them with Ibn Taimiyyah's thoughts in general. This research shows that beliefs about Khidhir's life or death are beliefs based on legitimate sources.
\end{abstract}

Keywords: Ibn Taimiyyah, Khidhir.

\section{Pendahuluan}

Sebagai seorang manusia biasa, para ulama pasti mengalami perkembangan pemikiran. Perkembangan pemikiran ini terjadi ketika adanya perubahan dalam masalah kematangan keilmuan. Fawa-fatwa yang dikeluarkan oleh para ulama tergantung kondisi kematangan keilmuannya. Maka ketika kondisi keilmuannya berubah, bisa jadi fatwa yang dikeluarkan pun bisa mengalami perubahan. Perubahan fatwa ini sering terjadi, baik dari kalangan ulama kontemporer atau bahkan ulama dari kalangan sahabat sekalipun.

Salah satu yang menarik untuk dikaji adalah fatwa-fatwa terkait masih hidunya Nabi Khidhir. Banyak sekali para ulama yang memberikan fatwa berkaitan dengan masalah Khidhir. Dalam dunia Islam, Khidhir dianggap sebagai sosok yang istimewa sekaligus misterius. Ke"misterius"an Khidhir ini justeru yang menjadikannya menjadi 
menarik untuk dikaji. Salah satu masalah yang muncul dalam perbincangan ulama adalah mengenai status kehidupan Khidhir sampai sekarang.

Pada dasarnya, pandangan mengenai masalah hidupnya Khidhir di kalangan ahlsussunnah wa al-jamaah merupakan masalah yang sangat kursial. Ada dua pendapat yang bertentangan dalam masalah ini. Satu kalangan mengatakan bahwa Khidhir masih hidup. Di antara ulama yang memfatwakan masalah ini adalah Ibn Shalah dan al-Nawawi. sedangkan kalangan yang lainnya mengatakan bahwa Khidhir sudah wafat. Di antara ulama yang memfatwakan masalah ini adalah Ibn Taimiyyah, Ibn Qayyim al-Jauziyyah, dan mayoritas madzhab Hanbali yang lainnya. Yang menarik dalam hal ini adalah bahwa kedua fatwa bertentangan di atas masing-masing difatwakan oleh para ahli hadits.

Namun dari kedua fatwa di atas ditemukan dua fatwa yang bertentangan dari seorang ulama karismatik Ibn Taimiyyah. Dalam kitab Majmû' Fatâwâ, 'Abdurrahman ibn Qasim memasukkan dua jenis fatwa dari Ibn Taimiyyah. Yang pertama menyatakan Khidhir sudah wafat dan kedua menyatakan masih hidup.

Tulisan ini akan mencoba mengkaji kedua jenis fatwa Ibn Taimiyyah tersebut. Penulis akan mencoba membandingkan kedua jenis fatwanya kemudian menganalisisnya berdasarkan dengan fatwa-fatwa Ibn Taimiyyah lainnya, baik yang ditulis oleh Ibn Taimiyyah sendiri ataupun yang dituliskan oleh para murid dan pengikutnya.

\section{Biografi Khidir}

\section{Kehidupan Khidhir}

Al-Khidhir (Arab: الخضر ) adalah seorang nabi yang dituturkan oleh Allah Swt. dalam al-Qur'an Surat al-Kahfi ayat 65-82. Selain kisah tentang Nabi Khidhir As. yang mengajarkan tentang ilmu dan kebijaksanaan kepada Nabi Musa As., asal-usul dan kisah lainnya tentang Nabi Khidhir As. tidak banyak disebutkan.

Dalam Mystical Dimensions of Islam, Annemarie Schimmel menyebutkan bahwa Nabi Khidhir As. dianggap sebagai salah satu nabi dari empat nabi 'yang dianggap masih hidup' atau 'abadi'. Tiga lainnya adalah Idris (Henokh), Ilyas (Elia), dan Isa (Yesus). ${ }^{1}$

\footnotetext{
${ }^{1}$ Annemarie Schimmel, Mystical Dimensions of Islam (Chapel Hill: University of North Carolina Press. 1975), 202.
} 
Nabi Khidhir As. abadi karena ia dianggap telah meminum air kehidupan. Ada beberapa pendapat yang menyatakan bahwa Nabi Khidhir As. adalah orang yang sama dengan seseorang yang bernama Elia. ${ }^{2}$ Nabi Khidhir As. juga diidentifikasikan sebagai St. George. ${ }^{3}$

Dalam kisah literatur Islam, satu orang bisa bermacam-macam sebutan nama dan julukan yang telah disandang oleh Nabi Khidhir As. Beberapa orang mengatakan Khidhir adalah nama gelarnya, yang lainnya menganggapnya sebagai nama julukan (laqab). ${ }^{4}$

Al-Khidhr secara harfiah berarti "Seseorang yang Hijau" melambangkan kesegaran jiwa, warna hijau melambangkan kesegaran akan pengetahuan "berlarut langsung dari sumber kehidupan." Adapula yang menyebutkan bahwa hijau itu menggambarkan ketampanan.

Ada banyak pertentangan mengenai identitas Khidhir sebenarnya. Ibn 'Asakir menyatakan bahwa Khidhir adalah anak keturunan Adam. Pernyataan ini didukung oleh riwayat al-Daruquthni yang bersumber dari sahabat Ibn 'Abbas. Abu Hatim al-Sijistani menyatakan bahwa Khidhir adalah anak adam yang paling panjang umurnya. Nama dia adalah Khudrun ibn Qabil ibn Adam. ${ }^{5}$

Menurut sebagian pedapat, nama Nabi Khidir ialah Balya ibn Malkan ibn Faligh ibn 'Abir ibn Syalikh ibn Arfakhsyaz ibn Sam anak dari Nabi Nuh. Dan gelarannya pula ialah Abu al-Abbas. Beliau juga dikenali dengan panggilan Khidir kerana dua sebab. Sebab pertama ialah berdasar pernyataan Rasulullah Saw yang menyatakan bahwa ia dinamakan Khidir kerana ketika ia duduk di atas rumput tiba-tiba memancar cahaya hijau dari arah belakangnya. Sebab kedua ialah psebagaimana pernyataan al-Khattaby yang mengatakan bahwa dia dinamakan Khidir kerana wajahnya tampan dan berseri-seri. ${ }^{6}$

\footnotetext{
2 "Muslim version of Elijah" George K. Anderson. The Legend of the Wandering Jew (Providence: Brown University Press. 1965), 409; Exhaustive material on Khidr's resemblance with Elijah is presented in Friedlaenders "Khidr" in the Encyclopedia of Religion and Ethics (New York: Charles Scribner's Sons, 1915), 693-95. 23.

${ }^{3}$ Peter L. Wilson, “The Green Man: The Trickster Figure in Sufism”, in Gnosis Magazine 1991,

${ }^{4}$ Alexander H. Krappe. The Science of Folklore (New York: Barnes and Noble Inc., 1930), 103.

${ }^{5}$ Ibn Katsir, Qashash al-Anbiyâ', (Kairo: Dar al-Ta'lif, 1974), juz 2, hal. 214.

${ }^{6}$ Ibn Katsir, al-Bidâyah wa al-Nhâyah, jilid 1, hal. 327.
} 
Ayah Khidhir adalah seorang Persia dan ibunya dari Romawi. ${ }^{7}$ Khidhir hidup pada masa raja Afridun dan akhirnya sampai bertemu dengan Nabi Musa. Ibn Katsir menyatakan banyak bukti yang menunjukkan bahwa Khidhir mengalami masa kepemimpinan Fir'aun. ${ }^{8}$

\section{Status Kenabian Khidhir}

Para sejarawan muslim berbeda pendapat mengenai status kenabian Khidhir. Mereka terbagi menjadi tiga kelompok:

Kelompok pertama mengatakan bahwa Khidhir adalah seorang malaikat yang memiliki fisik seperti Adam. Menurut Imam al-Nawawi, pendapat ini merupakan pendapat yang sangat aneh dan juga tidak bisa dipertanggungjawabkan. Hal senada juga diungkapkan oleh Ibn Katsir. ${ }^{9}$

Kelompok kedua mengatakan bahwa Khidhir adalah seorang wali. Pendapat ini diutarakan oleh sekolompok dari golongan sufi, Abu Ali ibn Abu Musa, Abu Bakar alAnbari, dan Abu al-Qasim al-Qusyairi. Pendapat ini didasari oleh sebagian pendapat yang lebih mengutamakan status wali dari pada nabi. Al-Hakim al-Tirmidzi dalam kitab khatam al-auliyâ' menyatakan bahwa ada sebagian wali yang melebihi status para nabi, dan salah satu wali tersebut adalah Khidhir. Bahkan beliau menegaskan bahwa akan ada wali terakhir yang lebih utama dari para sahabat. Keyakinan seperti ini juga dianut oleh Sa'd al-Din ibn Hamawaih dan Ibn 'Arabi penulis kitab al-Fushûsh dan Futûhât alMakiyyah. ${ }^{10}$

Pendapat di atas telah telah dibantah oleh Ibn Taimiyyah secara menyeluruh. Beliau mengatakan, "kaum muslimin sepakat bahwa Musa lebih utama daripada Khidhir. siapa saja yang meyakini bahwa Khidhir lebih utama dari Musa, baik Khidhir itu seorang nabi ataupun wali, maka dia kafir. Dan mayoritas ulama berpendapat bahwa Khidhir bukanlah nabi. Bahkan para nabi dari kalangan Bani Isra'il seperti Daud dan Sulaiman lebih utama daripada Khidhir. " Pendapat Ibn Taimiyyah ini juga dipertegas pula oleh keyakinan kalangan sufi bahwa puncak dari keilmuan seorang wali, termasuk juga

${ }^{7}$ Ibn Katsir, Qashash al-Anbiyâ', juz 2, hal. 216.

${ }^{8}$ Ibid.

9 Ibn Hajar al-'Asqalani, al-Zahr al-Nadhr fî Anbâ' al-Khadhir, (India: Majma' Buhuts alIslamiyyah, 1988), hal. 24.

${ }^{10}$ Ibid., hal.25. 
Khidhir, adalah kasyf. Sedangkan kasyf adalah salah satu bagian dari kenabian. Lalu bagaimana mungkin bisa dikatakan bahwa status wali lebih tinggi dari nabi? ${ }^{11}$

Kelompok kedua ini berargumen dengan kisah Khidhir dan Musa dalam QS alKahfi yang mereka klaim bahwa Khidhir tidak mengikuti syari'at Musa. Namun pendapat ini dibantah oleh Ibn Taimiyyah dari dua segi; Pertama, bahwa apa yang dilakukan oleh Khidhir tidak keluar dari apa yang digariskan oleh syari'at Musa. Hal ini terbukti dengan afirmasi Musa kepada Khidhir setelah Khidhir menjelaskan semua rahasia kejadian yang dialami Musa. Kedua, Khidhir bukanlah termasuk umat Nabi Musa. Musa hanyalah diutus kepada Bani Isra'il saja, sedangkan Khidhir bukanlah bagian dari Bani isra'il. Maka keluarnya Khidhir dari syari'at Musa bukan karena keutamaannya, tapi karena dia bukan termasuk umat Musa. Maka dengan pemaparan dari Ibn Taimiyyah ini, terlihat jelas bahwa kalangan yang berpendapat bahwa seseorang boleh keluar dari syari'at dan menggantinya dengan ilmu laduni, merupakan pendapat yang tidak bisa diterima. ${ }^{12}$

Kelompok ketiga mengatakan bahwa Khidhir adalah seorang Nabi. Pendapat ini adalah pendapat dari mayoritas ulama dan peneliti. Pendapat ini dikemukakan oleh alTsa'labi, al-Qurthubi, al-Alusi, dan yang lainnya. Ibn Hajar al-'Asqalani memilih pendapat ketiga ini dengan memaparkan berbagai argumentasinya;

Pertama, dalam al-Quran ada beberapa ayat yang mengindikasikan kenabian Khidhir. Dalam QS al-Kahfi: 65 Allah berfirman:

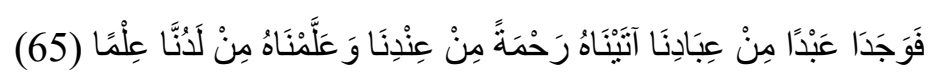

lalu mereka bertemu dengan seorang hamba di antara hamba-hamba Kami, yang telah Kami berikan kepadanya rahmat dari sisi Kami, dan yang telah Kami ajarkan kepadanya ilmu dari sisi Kami.

Yang dimaksud dengan "rahmat di sisi Kami" menurut mayoritas mufassir maknanya adalah kenabian.

Allah juga berfirman:

\footnotetext{
${ }^{11}$ Ibid., hal. 26-27.

12 Ibid., hal. 29.
} 


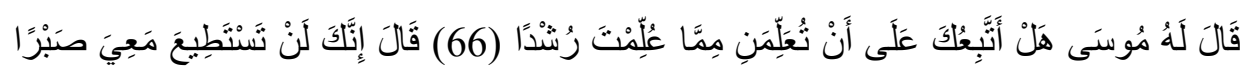

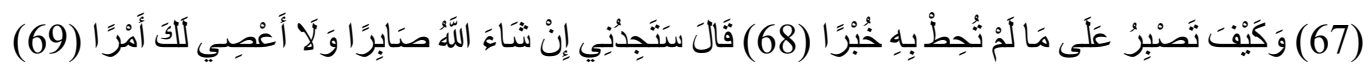

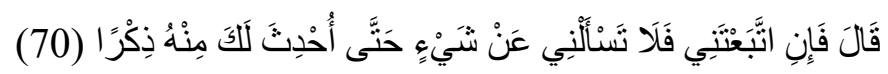

66. Musa berkata kepada Khidhr: "Bolehkah aku mengikutimu supaya kamu mengajarkan kepadaku ilmu yang benar di antara ilmu-ilmu yang telah diajarkan kepadamu?" 67. Dia menjawab: "Sesungguhnya kamu sekali-kali tidak akan sanggup sabar bersama aku. 68. dan bagaimana kamu dapat sabar atas sesuatu, yang kamu belum mempunyai pengetahuan yang cukup tentang hal itu?" 69. Musa berkata: "Insya Allah kamu akan mendapati aku sebagai orang yang sabar, dan aku tidak akan menentangmu dalam sesuatu urusanpun". 70. Dia berkata: "Jika kamu mengikutiku, Maka janganlah kamu menanyakan kepadaku tentang sesuatu apapun, sampai aku sendiri menerangkannya kepadamu".

Kalaulah seandainya dia itu seorang wali dan bukan nabi tidak mungkin Musa memaksa untuk terus menemani Khidhir. Dan kalaulah Khidhir bukan seorang nabi maka dia tidak $m a$ 'shûm dan tidak ada gunanya nabi semulia Musa merasa perlu untuk terus mengikuti Khidhir.

Kemudian pada ayat selanjutnya diebutkan bahwa Khidhir langsung membunuh seorang anak, yang dimana kalaulah dia seorang wali maka tidak halal baginya untuk melakukan hal tersebut.

Dan pada QS al-Kahfi: 82 disebutkan

$$
\text { وَمَا فَعَتْتُهُ عَنْ أَمْرِي }
$$

dan bukanlah aku melakukannya itu menurut kemauanku sendiri.

ayat di atas semakin mempertegas bahwa Khidhir melakukan semua itu bukan atas dasar kemauannya, namun wahyu dari Allah Swt. Allah menyatakan dalam QS alJin: 26

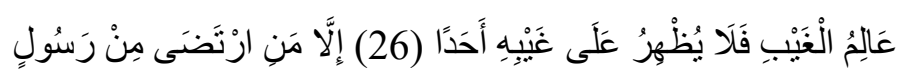

(dia adalah Tuhan) yang mengetahui yang ghaib, Maka Dia tidak memperlihatkan kepada seorangpun tentang yang ghaib itu. 27. kecuali kepada Rasul yang diridhai-Nya. 
Dari beberapa pemaparan di atas, jelaslah bahwa Khidhir adalah seorang nabi Allah yang diutus berbarengan dengan kenabian Musa sebagaimana Harun. ${ }^{13}$

\section{Pandangan Ibn Taimiyyah tentang Khidhir}

\section{Biografi Ibn Taimiyyah}

Nama beliau adalah Taqiyuddin Abdul Abbas Ahmad ibn Abdul Salam ibn Abdullah al-Khidr ibn Muhammad al-Khidr ibn 'Ali ibn Abdullah. Atau lebih dikenal dengan nama Ibn Taimiyah.

Ibn Taimiyah lahir di Harran, pada 10 Rabiul Awwal 661 Hijriah, atau 22 Januari 1263 Masehi. Lima tahun sebelum kelahirannya, Kota Baghdad yang merupakan pusat khasanah keilmuan Islam takluk oleh invasi bangsa Mongol. Tak terhitung jumlah kerugian akibat invasi ini, namun yang lebih menyedihkan, begitu banyak naskah keilmuan Islam yang hilang dan rusak. Hanya berselang 11 tahun kemudian, atau pada saat Ibn Taimiyah berusia 6 tahun (667 Hijriah), Kota kelahirannya, yang masuk wilayah Mesopotamia Utara (kini masuk dalam wilayah Turki, dekat perbatasan Irak), diserang pasukan Tartar. Akibat serangan ini, Ibu Taimiyah dan keluarganya mengungsi ke Damaskus, Syiria. ${ }^{14}$

Berlatar belakang mahzab Hanbali yang kental, keluarga Ibn Taimiyah diterima dengan tangan terbuka di Damaskus. Di tempat baru ini, Ayah Ibn Taimiyah, yang juga merupakan salah seorang alim ulama terkemuka pada masa itu, mendapat tempat berlabuh yang layak di Universitas Masjid Jami’ Bani Umayyah. Dasar keilmuan agama Ibn Taimiyah didapatnya dari Ayahnya sendiri. Demikian cemerlangnya ia diusia muda, hingga pada usia masih belasan tahun, ia sudah dipercaya sesekali menggantikan ayahnya memberi kuliah di Universitas masjid tersebut. ${ }^{15}$

Beliau dikenal sebagai orang yang sangat fokus dalam menyeru untuk kembali pada Kitab suci dan Sunnah. Beliau juga mengajak untuk meneladani kaum salaf yang saleh (al-Salaf al-Shalih), yaitu kaum Muslim dari tiga generasi pertama yang meliputi

13 Ibid., hal. 32.

${ }^{14}$ Shalih Fauzan, Min Masyâhir Mujaddidayn fî al-Islâm, (KSA, 1417H), hal. 8.

${ }^{15}$ Shalahuddin al-Munajjid, Ibn Taimiyyah Sîratuh wa Akhbâruh, (Riyadh: Dar al-Salam, 1428H), hal. 57. 
para Sahabat Nabi, Tabi'in (para pengikut sahabat), dan Tabi'u al-Tabi'in (para pengikut tabi' in). ${ }^{16}$

Lahir dan tumbuh dalam masa dekadensi imperium Islam, Ibn Taimiyah memiliki pertentangan ilmiah dan ideologis terhadap para ulama yang kebetulan pada saat itu umumnya bermahzab Syafi'i. Ia mengkritik para ulama dan penguasa yang menurutnya sebagai sebab kemunduran Islam. Ia memandang, bahwa ulama dan penguasa adalah yang paling betanggungjawab atas semua kelemahan dan kemunduran umat saat itu.

Akibat kritik-kritiknya yang begitu keras ke semua pihak, ia harus berkali-kali mendekam dalam penjara. Di dalam penjara inilah ia banyak menulis kitab-kitab karangannya yang kemudian banyak berpengaruh di masyarakat. Kritik paling tajam ia arahkan pada kelompok-kelompok tarekat dan kaum syiah. Baginya kedua kelompok ini adalah pelaku bid'ah yang menyimpang dari tuntunan nilai agama yang murni dan asli. ${ }^{17}$

Ibn Taimiyah wafat di usia 67 tahun dalam penjara di Damaskus pada 728 Hijriah atau 1328 Masehi, setelah sakit dalam penjara lebih dari 20 hari. Dikabarkan ia dipenjara bersama salah satu murid terbaiknya, Ibn Qoyyim al-Jauziah. Pada masa selanjutnya, Ibn Qoyyim melanjutkan perjuangan gurunya, tapi dengan cara yang lebih lentur dan damai, meski tanpa mengurangi nilai-nilai ideologis yang didapat dari gurunya. ${ }^{18}$

2. Status Kenabian dan Masih Hidupnya Khidhir Menurut Ibn Taimiyyah

Syaikh al-Islam Ibn Taimiyyah pernah ditanya, “Apakah Khidhir itu seorang nabi ataukah wali? Apakah dia masih hidup sampai sekarang? Kalau memang benar masih hidup, lalu bagaimana dengan hadits yang menyebutkan bahwa "kalaulah sekiranya Khidhir masih hidup maka pasti dia akan menemuiku", apakah hadits tersebut shahih atau tidak?"

Maka Syaikh Ibn Taimiyyah menjawab: Mengenai masalah kenabian Khidhir, sesungguhnya baik Khidhir ataupun selainnya tidaklah mendapatkan wahyu sama sekali setelah diutusnya Rasulullah. Namun sebelum kenabian Rasulullah maka ada perbedaan pendapat mengenai kenabiannya ini, ada yang mengatakan bahwa dia itu adalah seorang

\footnotetext{
${ }^{16}$ Nurcholish Madjid, Kaki Langit Peradaban Islam, Jakarta, Dian Rakyat, 2009, Hal. 123

${ }^{17}$ Shalahuddin al-Munajjid, Ibn Taimiyyah, hal. 57.

${ }^{18}$ Ahmad Farid, 60 Biografi Ulama Salaf, terj. Ahmad Syaikhu, (Jakarta: Darul Haq, 2012), cet.
} I, hal. 900. 
nabi. Bahkan ada yang mengatakan bahwa dia itu sama seperti Ilyas. Namun dia pada masa-masa ini tidaklah mendapatkan wahyu, dan tidak adanya wahyu kepada Khidhir pada waktu-waktu tertentu tidaklah menafikan status kenabiannya sebagaimana wahyu perah terputus pada awal-awal diutusnya Rasulullah. Mayoritas ulama menyatakan bahwa dia itu bukanlah seorang nabi.

Adapun mengenai hidupnya Khidhir, maka dia masih hidup. Adapun hadits yang disebutkan (di pertanyaan) tidak memiliki asal sama sekali. Bahkan dalam musnad alSyafi'i diriwayatkan bahwa Khidhir bertemu dengan Nabi. Maka siapa saja yang mengatakan bahwa Khidhir tidak bertemu dengan Nabi maka dia telah mengatakan perkara tanpa ilmu, karena itu termasuk ilmu yang tidak bisa dipelajari.

Jadi siapa saja yang menyatakan Khidhir telah wafat dengan hujjah ada hadits yang menyatakan, "perhatikanlah malam ini, karena seratus tahun ke depan tidak akan tersisa, semua orang yang pada waktu ini ada di muka bumi ini”, maka hujjah ini tidak bisa diterima karena bisa jadi Khidhir pada waktu itu tidak tinggal di muka bumi. Karena telah disepakati bahwa Dajjal -begitu juga dengan Jassasah- sudah ada pada masa Nabi dan akan tetap hidup selama belum keluar. Dan dia tinggal di dalam lautan. ${ }^{19}$

Beliau juga menegaskan, "Begitupun dengan perbandingan Abu Bakar dan Khidhir adalah tergantung kenabian Khdhir. Mayoritas ulama menyatakan bahwa Khdhir bukanlah seorang nabi, dan ini adalah pilihan Abu Ali ibn Abu Musa serta ulama lainnya, maka dengan begitu Abu Bakar dan Umar lebih utama daripada Khidhir. Adapun bila orang yang berpendapat bahwa Khidhir adalah seorang nabi sebagaimana pilihan Abu alFaraj Ibn al-Jauzi dan yang lainnya, maka Khidhir lebih utama daripada Abu Bakar dan Umar. Tapi yang jelas bahwa Nabi Muhammad dan Isa ibn Maryam lebih utama daripada Khidhir. Nabi Muhammad adalah ujung awal dari ummat ini, sedangkan Isa ibn Maryam adalah akhirnya." 20

\section{Fatwa mengenai Wafatnya Khidhir}

Syaikh al-Islam Ibn Taimiyyah ditanya mengenai Khidhir dan Ilyas, "apakah keduanya masih hidup? Tolong jelaskanlah kepada kami semoga Allah merahmatimu".

\footnotetext{
${ }^{19}$ Ibn Taimiyyah, Majmû' Fatâwâ, jilid 4, hal. 438.

${ }^{20}$ Ibn Taimiyyah, Majmû' Fatâwâ, jilid 4, hal. 397.
} 
Ibn Taimiyyah menjawab, "baik Khidhir maupun Ilyas tidaklah termasuk yang masih diberi umur dan mereka berdua sudah tidak lagi hidup. Ibrahim al-Harbi pernah bertanya kepada Imam Ahmad ibn Hanbal mengenai usia Khidhir dan Ilyas serta banyak riwayat yang menyatakan bahwa keduanya masih hidup dan sering terlihat. Maka Imam Ahmad menjawab, "siapa yang berani memasikan perkara ghaib yang tidak diketahuinya? Pasti yang ditemuinya itu adalah syetan (bukan Khidhir ataupun Ilyas)".

Imam al-Bukhari pun pernah ditanya mengenai hidupnya Khidhir dan Ilyas, maka Imam al-Bukhari menjawab, "bagaimana mungkin itu bisa terjadi padahal Rasulullah sudah menjelaskan "perhatikanlah malam ini, karena seratus tahun ke depan tidak akan tersisa, semua orang yang pada waktu ini ada di muka bumi ini’?"

Abu al-Faraj Ibn al-Jauzi mengatakan bahwa kedunya sudah mati berdasarkan ayat

\section{وَمَا جَعَلْنَا لِبَشَرِ مِنْ فَبَلِلَكَ الْخُلْدَ}

"dan Kami tidaklah sama sekali menjadikan orang-orang sebelum kamu itu hidup kekal'. (al-Anbiya: 34) Wallahu A'lam. ${ }^{21}$

Ibn al-Jauzi menulis sebuah kitab dalam masalah ini. Kitab tersebut berjudul 'Ajâlat al-Muntadzir fì Syarh Hâl al-Khidhir. Ibn Katsir menyebutkan dalam alBidâyah wa al-Nihâyah mengatakan, "adapun orang-orang yang berpendapat bahwa Khidhir sudah wafat di antaranya adalah al-Bukhari, Ibrahim al-Harbi, Abu al-Hasan alMunadi, dan Syaikh Abu al-faraj Ibn al-Jauzi yang membela pendapat ini dengan kitabnya yang berjudul 'Ajâlat al-Muntadzir fî Syarh Hâl al-Khidhir. Dalam kitabnya tersebut, Ibn al-Jauzi berhujjah mengenai wafatnya Khidhir dengan Firman Allah: ,'Dan tidaklah kami jadikan seorang pun sebelum kamu sebagai manusia kekal”. Kalaulah seandainya Khidhir adalah seorang mausia, maka dia termasuk ke dalam ayat ini. Dan tidak ada satu riwayatpun yang menjelaskan pengkhususan Khidhir dari ayat ini. ${ }^{22}$

Dalam fatwanya yang lain, Ibn Taimiyyah juga mengatakan, Semua bentuk kemusyrikan yang dijelaskan oleh al-Quran sebenarnya bermuara pada dua bentuk, yaitu kaum Nuh yang sumber kemusyrikan mereka ada pada pengagungan yang berlebihan

\footnotetext{
${ }^{21}$ Ibn Taimiyyah, Majmû' Fatâwâ, jilid 3, hal. 337.

${ }^{22}$ Ibn Katsir, al-Bidâyah wa al-Nihâyah, juz 2, hal. 265.
} 
kepada orang-orang shaleh dan kemudian mereka menyembah kuburan-kuburan serta patung-patung mereka, dan kaum Ibrahim yang kemusyrikan mereka bersumber kepada benda-benda langit seperti ibntang, matahari, dan bulan.

Meskipun bentuk kemusyrikan mereka berbeda namun pada hakikatnya sama, yaitu sama-sama menyembah jin. Sebenarnya syetan-lah yang mengajak dan membantu mereka untuk melakukan berbagai bentuk kemusyrikan tersebut namun mereka malah meyakininya sebagai ajakan malaikat. Padahal hanya syetan-lah yang mendorong mereka kepada kemusyrikan serta meridhainya. Allah berfirman

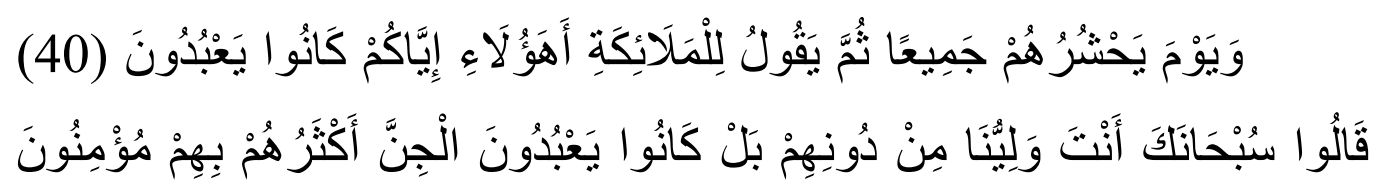

"Dan ingatlah pada hari ketika Allah mengumpulkan mereka semuanya kemudian Allah berfirman kepada pada malaikat, "apakah kepada kalian mereka ini dahulu menyembah?" (40) Para malaikat itu menjawab, "Maha Suci Engkau. Engkaulah Pelindung kami dan bukan mereka. Tapi mereka sebenarnya menyembah jin, dan sebenarnya kebanyakan mereka beriman kepada jin (41).”

Sebenarnya para malaikat tidak mungkin mendorong mereka pada kemusyrikan, baik ketika hidup maupun sudah mati, dan mereka pun tidak mungkin meridhainya. Namun sebenarnya setelah yang telah merubah wujudnya menjadi wujud manusia dan orang musyrik tersebut melihat jin itu dengan mata mereka sendiri dan kemudian jin itu mengatakan, “aku Ibrahim”, “aku al-Masih”, “aku Muhammad”, “aku Khidhir”, “aku Abu Bakar", “aku Umar”, “aku Utsman”, “aku Ali”, “aku Syaikh Fulan”, dan begitu seterusnya. Bahkan ada di antara para jin itu yang mengatakan kepada jin yang lainnya, “ini adalah Nabi Fulan" atau "ini adalah Khidhir", padahal semuanya adalah jin yang saling memberikan persaksian di antara mereka. Karena jin itu seperti manusia, ada yang kafir, ada yang fasiq, ahli maksiat, ahli ibadah yang bodoh, dan di anatara merekapun ada yang menyukai seorang syaikh dan kemudian jin tersebut menjirim menjadi syaikh tersebut dan mengatakan, "aku adalah Syaikh Fulan”. Kadang hal itu terjadi di sebuah daerah yang kosong dan tandus, kemudian datanglah seseorang yang memberi makanan dan minuman, atau memberikan sebuah petunjuk dan berita ghaib yang akan terjadi, maka orang-orang menyangkanya sebagai Syaikh Fulan. Namun sebenarnya dia adalah jin, 
karena malaikat tidak mungkin mendorong kepada kemusyrikan, dusta, dosa, dan permusuhan. $^{23}$

Di antara mereka ada yang berkeyakinan pernah melihat Allah, maka dia dan kaumnya meyakini bahwa mereka benar-benar melihat Allah dalam keadaan sadar, bahkan mereka berani memberikan sumpah atas persaksiannya itu. Bisa jadi mereka benar dengan apa yang mereka saksikan, namun mereka tidak mengetahui bahwa yang mereka lihat itu sebenarnya adalah syetan. Hal ini sering terjadi kepada orang-orang yang bodoh. Di antara mereka menyangka bahwa dia benar-benar melihat Allah dengan kedua matanya di dunia. Karena kebanyakan mereka hanyalah berprasangka saja bahwa itu adalah Allah, padahal itu adalah syetan.

Banyak pula di antara mereka yang melihat seseorang yang dikiranya bahwa orang tersebut adalah seorang nabi, orang shaleh, ataupun Khidhir yang sebenarnya semua itu adalah syetan. Karena sudah tertera dalam hadits shahih dari Nabi bahwa Beliau mengatakan, "siapa yang melihatku dalam mimpi, maka dia benar-benar telah melihatku karena syetan tidak bisa menyerupaiku". Hal ini terjadi hanya dalam mimpi saja, karena mimpi itu terkadang dari Allah dan terkadang dari syetan dan Allah telah mencegah syetan untuk menyerupai Nabi. Adapun dalam keadaan terjaga, tidak mungkin ada seseorang yang bisa melihatnya di dunia ini. ${ }^{24}$

Tidak ada satupun bukti yang menunjukkan bahwa para sahabat ada yang secara sengaja berdusta atas nama Nabi, sebagaimana tidak ada bukti yang menunjukkan bahwa mereka melakukan bid'ah seperti bid'ah Khawarij, Rafidhah, Qadariyyah, ataupun Murjiah, ataupun masuk ke dalam salah satu firqah tersebut. Tidak sebagaimana orangorang yang mengaku didatangi oleh Khidhir, karena sesungguhnya Khidhir yang bersama Musa telah wafat sebagaimana yang telah dijelaskan di lain tempat. Dan Khidhir yang disebut-sebut banyak dijumpai oleh banyak orang sebenarnya adalah jin yang menjirim menjadi manusia atau bisa jadi itu adalah seorang manusia yang pandai berdusta. Tidak mungkin ada seorang malaikat yang mengatakan "aku adalah Khidhir" karena malaikat tidak mungkin berbohong, karena yang bisa berbohong hanyalah jin dan manusia. Dan aku hafal mengenai orang-orang yang mengaku didatangi oleh Khidhir, dan kalau aku

\footnotetext{
${ }^{23}$ Ibn Taimiyyah, Majmû' Fatâwâ, jilid 1, hal. 158.

${ }^{24}$ Ibn Taimiyyah, Majmû' Fatâwâ, jilid 1, hal. 172.
} 
sebutkan di tempat ini maka itu akan terlalu panjang. Dan yang jelas para sahabat itu lebih berilmu dibandingkan dengan orang-orang yang masyhur tertipu oleh iblis ini. ${ }^{25}$

Banyak orang yang mengaku bahwa dia melihat seseorang yang mengaku Khidhir, padahal dia adalah jin. Maka berdasarkan pengalaman beberapa orang ini banyak yang tidak menerima pendapat yang menegaskan wafatnya Khidhir. Bahkan ada sebagian yang berani memastikan bahwa Khidhir masih hidup. Pendapat ini adalah pendapat yang keliru.

Bisa dikatakan bahwa banyak orang yang jujur dalam pengakuannya bahwa mereka bertemu dengan Khidhir, namun sebenarnya mereka keliru dalam sangkaan mereka. Mereka memang benar melihat wujud Khidhir, namun sebenarnya dia adalah jin yang menyerupai Khidhir. Bahkan kejadian seperti ini banyak dialami oleh orang-orang Yahudi dan Nashrani di tempat-tempat peribadatan mereka. ${ }^{26}$

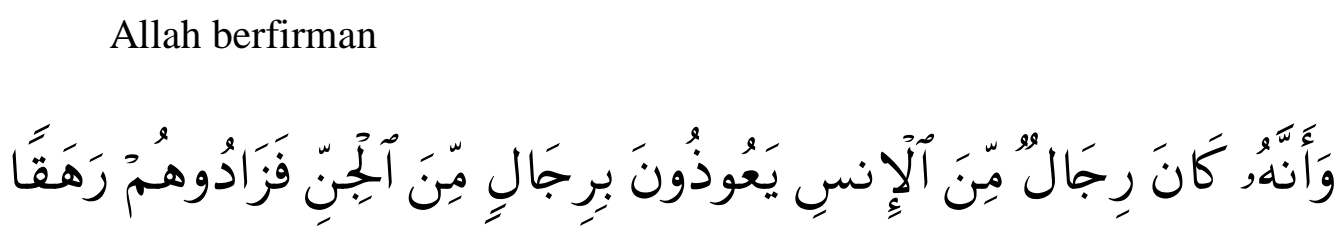

"Dan bahwasanya ada beberapa orang laki-laki di antara manusia meminta perlindungan kepada beberapa laki-laki di antara jin, Maka jin-jin itu menambah bagi mereka dosa dan kesalahan".

Begitu pula dengan orang yang melihat Khidhir, dia adalah jin yang mnegakungaku Khidhir. Karena sesungguhnya Khidhir yang bertemu degan Musa sudah mati. Kalaulah seandainya dia masih hidup pada masa Rasulullah Saw, maka wajib bagi Khidhir untuk menemui Nabi dan beriman kepadanya, dan wajib pula baginya untuk ikut berjihad bersama Nabi. Karena sesungguhnya Allah mewajibkan kepada siapa saja yang semasa dengan Nabi untuk beriman kepadanya dan berjihad bersamanya, meskipun dia adalah seorang nabi. Sebagaimana Firman Allah:

${ }^{25}$ Ibn Taimiyyah, Majmû' Fatâwâ, jilid 1, hal. 249. 


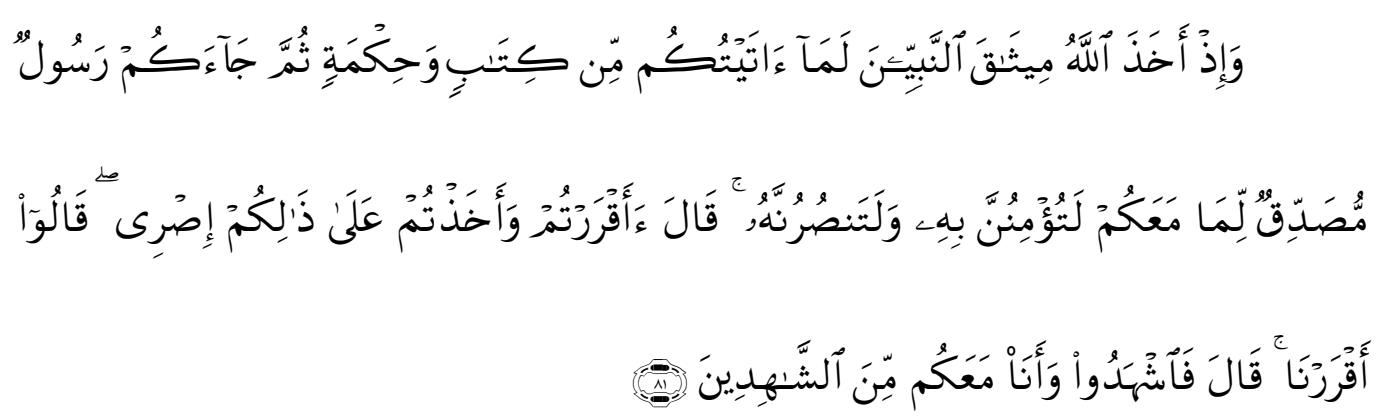

Dan (ingatlah), ketika Allah mengambil Perjanjian dari Para nabi: "Sungguh, apa saja yang aku berikan kepadamu berupa kitab dan Hikmah kemudian datang kepadamu seorang Rasul yang membenarkan apa yang ada padamu, niscaya kamu akan sungguh-sungguh beriman kepadanya dan menolongnya". Allah berfirman: "Apakah kamu mengakui dan menerima perjanjian-Ku terhadap yang demikian itu?" mereka menjawab: "Kami mengakui". Allah berfirman: "Kalau begitu saksikanlah (hai Para Nabi) dan aku menjadi saksi (pula) bersama kamu".

Ibn Abbas mengatakan, "para Nabi berjanji kepada Allah s.w.t. bahwa bilamana datang seorang Rasul bernama Muhammad mereka akan iman kepadanya dan menolongnya. Perjanjian nabi-nabi ini mengikat pula Para ummatnya, bahwa mereka akan beriman dan menolong Nabi Muhammad sekiranya mereka bertemu dengan beliau.

Tidak ada satupun riwayat yang menyebutkan bahwa ada sahabat yang mengaku bertemu dengan Khidhir atau Khidhir mendatangi Nabi Saw, padahal sahabat adalah generasi yang paling berilmu dan paling mulia sehingga setan tidak bisa mengelabui mereka. Namun setan berhasil mengelabui generasi setelah mereka. Setan menampakkan pada salah seorang di antara mereka dan menyerupai seorang nabi kemudian mengaku sebagai Khidhir. ${ }^{27}$

\section{Perbandingan antara Kedua Fatwa}

Mengenai fatwa Ibn Taimiyyah yang menyatakan Khidhir masih hidup, Nashir Hamid al-Fahd dalam catatan kakinya terhadap kitab Majmû' Fatâwâ menyatakan bahwa penyadur ('Abdurrahman ibn Qasim) meragukan fatwa Syaikh al-Islam ini. Hal ini bisa

\footnotetext{
${ }^{27}$ Ibn Taimiyyah, Majmû' Fatâwâ, jilid 27, hal. 17-19.
} 
dilihat dari pernyataan terakhirnya yang menyatakan bahwa "beginilah aku mendapatkan fatwa ini". Seolah-olah Abdurrahman ibn Qasim menyatakan bahwa itu bukanlah fatwa asli dari Ibn Taimiyyah. Pernyataan ini dikeluarkan oleh Abdurrahman ibn Qasim setelah beliau membandingkannya dengan seluruh fatwa Ibn Taimiyyah yang tentang Khidir. Di antaranya adalah:

1. Fatwa Ibn Taimiyyah yang dicantumkan sebelum fatwanya ini. Dimana ketika beliau ditanya tentang Khidhir dan Ilyas beliau menolak bahwa keduanya termasuk orang yang masih hidup atau berumur panjang.

2. Pada jilid 1 hal. 249 beliau mengatakan, "Sesungguhnya Khidhir dan Musa sudah wafat sebagaimana yang telah saya jelaskan pada tempat yang lain”.

3. dalam kitab minhâj al-sunnah jilid 4 hal. 93 beliau mengatakan, "semua pendapat para ahli mengatakan bahwa Khidhir telah mati”.

4. Dalam Majmu' fatawa jilid ke 27 hal. 100-101 beliau mengatakan, "sebagaimana yang ditegaskan oleh para peneliti bahwa yang benar Khidhir itu telah mati. Khidhir tidak mengalami masa Islam. Kalaulah Khidhir masih hidup pada masa Islam maka wajib baginya untuk beriman kepada Muhammad Saw, berjihad bersamanya, sebagaimana Allah juga mewajibkan hal yang sama kepada selainnya. Kalaulah seandainya Khidhir ada di Mekkah atau Madinah maka bisa dipastikan bahwa kehadirannya bersama para sahabat dalam musyawarah atau peperangan mereka lebih utama daripada kehadirannya saat melubangi perahu. Sangatlah tidak layak bagi Khidhir untuk menyembunyikan darinya di hadapan ummat terbaik ini. Kalaulah memang benar Khidhir masih hidup, lalu mengapa Rasulullah Saw tidak mengabarkannya kepada ummatnya ataupu salah satu khulafaurrasyidinnya?!"

5. apa yang disebutkan oleh Ibn Abdilhadi dalam kitab 'uqûd al-durriyyah setelah beliau menuliskan karya-karya syaikh al-Islam Ibn Taimiyyah pada hal. 70 beliau mengatakan, "Jawaban Ibn Taimiyyah menganai mati atau hidupnya Khidhir maka pendapat yang terpilih darinya bahwa Khidhir telah mati”.

Setiap orang yang fokus mengkaji pemikiran Ibn Taimiyyah yang berkaitan dengan masalah hidupnya Khidhir akan merasa heran dengan satu-satunya fatwa Ibn Taimiyyah pada jilid terakhir ini, yang menyatakan masih hidunya Khidhir, dimana tidak ada fatwa lainnya yang menyatakan hal yang sama. Bahkan seluruh fatwanya 
bertentangan dengan hal ini. Maka fatwa Ibn Taimiyyah ini mengundang beberapa pertanyaan, yang terpenting adalah:

1. Mengapa Ibn taimiyyah berdalil dengan hadits yang menjelaskan pertemuan Khidhir dengan Rasulullah Saw, padahal di tempat yang lain Ibn Taimiyyah memastikan bahwa Khidhir tidak mengalami zaman Islam. Lalu bagaimana mungkin Khidhir bisa bertemu dengan Nabi Saw?

2. Mengapa Ibn taimiyyah mengomentari hadits mengenai "matinya semua orang yang hidup seratus tahun ke depan" dengan menganggap Khidhir tidak tercakup hadits tersebut karena Khidhir hidup di bawah laut. Namun pada tempat yang lain Ibn Taimiyyah justeru menggunakan hadits ini dengan mengutip pendapat Imam al-Bukhari, Imam Ahmad, dan ulama lainnya sebagai dalil wafatnya Khidhir.

3. Mengapa beliau juga berdalil dengan hadits yang berkaitan dengan Perang Badar dimana semua peserta Badar sudah tercantum dengan jelas dalam buku-buku sejarah, dan mengapa Khidhir tidak terdaftar di dalamnya? Apakah Ibn Taimiyyah melupakan dalilnya ini?

4. Mengapa murid terbaiknya, Ibn Qayyim al-Jauziyyah, justeru berpendapat dengan tegas bahwa Khidhir sudah wafat. Apakah mungkin muridnya ini berani meninggalkan pendapat gurunya sendiri? Bukankah Ibn Qayyim sendiri dalam kitab asmâ' muallafât Ibn Taimiyyah menyatakan bahwa Ibn taimiyyah menulis dua kitab mengenaai Khidhir dan juga kedua kitab tersebut merupakan rujukannya?

Semua pertanyaan di atas pasti muncul pada benak para pengkaji pemikiran Ibn Taimiyyah. Maka untuk menjawab semua persoalan di atas, maka seorang pengkaji harus memahami tiga kemungkinan dari fatwa Ibn Taimiyyah tersebut;

1. Bisa jadi pendapat Ibn Taimiyyah mengenai masih hidupnya Khidhir merupakan pendapatnya yang paling râjih. Namun kemungkinan ini terbantahkan dengan sekian banyaknya fatwa Ibn Taimiyyah yang menerangkan kematian Khidhir. Sedangkan fatwa Ibn Taimiyyah berkenaan dengan masih hidupnya Khidhir hanya tercantum dalam fatwanya ini. Bahkan fatwanya ini bertentangan dengan kebiasaan Ibn taimiyyah sendiri yang selalu mengulang-ulang fatwanya dalam berbagai tempat. 
2. Kemungkinan lainnya, bisa jadi bahwa pendapat Ibn Taimiyyah mengenai masih hidupnya Khidhir merupakan pendapatnya yang dulu dan sudah dihapus dengan pendapatnya mengenai wafatnya Khidhir. Kemungkinan ini lebih mendekati kebenaran kalau ditinjau dari segi karya-karya Ibn Taimiyyah dan manhajnya dalam masalah 'aqidah, serta berpegangnya beliau kepada al-Quran dan sunnah yang shahih. Hal ini juga bisa dibuktikan dengan fatwa muridnya, Ibn al-Qayyim, yang merajihkan pendapat mengenai wafatnya Khidhir.

3. Bahkan bisa jadi pendapat ini bukanlah pendapatnya Ibn Taimiyyah. Hal ini ditinjau dari beberapa aspek. Di antaranya ialah komentar dari Syaikh Abdurrahman ibn Muhammad ibn Qasim al-'Ashimi al-Najdi al-Hanbali, penyunting dan editor kitab Majmû' Fatâwâ Ibn Taimiyyah, di akhir fatwa Ibn Taimiyyah ini. Beliau mengatakan, "beginilah fatwa yang saya dapatkan”. Padahal komentarnya ini di luar kebiasaannya.

Hemat penulis, komentarnya ini terpaksa beliau tulis setelah melihat fatwa Ibn Taimiyyah ini menyimpang dari kebiasaan fatwanya. Komentar ini hanya bisa dimengerti oleh orang yang sudah mengkaji secara intens fatwa-fatwa dari Ibn Taimiyyah. Di antara beberapa fatwa ulama ditemukan adanya fatwa yang sangat mirip dengan fatwa ini. Fatwa tersebut berasal dari Ibn Shalah. Bisa jadi fatwa ini justeru berasal dari Ibn Shalah, dan bukan dari Ibn Taimiyyah.

\section{Penutup}

Dari beberapa pemaparan di atas dapat disimpulkan bahwa kedua fatwa Ibn Taimiyyah di atas menggambarkan perkembangan pemikiran Ibn Taimiyyah. Dan kalaupun fatwa mengenai masih hidupnya Khidhir bukan fatwa orisinil dari Ibn Taimiyyah, namun bisa dikatakan bahwa keyakinan masih hidunya Khidhir masih dalam koridor kepercayaan ahlussunnah wal jama'ah. 


\section{DAFTAR PUSTAKA}

Ahmad Farid, 60 Biografi Ulama Salaf, terj. Ahmad Syaikhu, (Jakarta: Darul Haq, 2012), cet. I.

Annemarie Schimmel, Mystical Dimensions of Islam, (Chapel Hill: University of North Carolina Press. 1975).

Alexander H. Krappe. The Science of Folklore (New York: Barnes and Noble Inc., 1930).

Ibn Katsir, Qashash al-Anbiyâ', (Kairo: Dar al-Ta'lif, 1974), juz 2, hal. 214.

Ibn Katsir, al-Bidâyah wa al-Nihâyah, (Beirut: Dar al-Fikr, 2000).

Ibn Hajar al- 'Asqalani, al-Zahr al-Nadhr fí Anbâ' al-Khadhir, (India: Majma' Buhuts alIslamiyyah, 1988).

Nurcholish Madjid, Kaki Langit Peradaban Islam, (Jakarta: Dian Rakyat, 2009).

Peter L. Wilson, “The Green Man: The Trickster Figure in Sufism”, in Gnosis Magazine 1991, 23.

Shalahuddin al-Munajjid, Ibn Taimiyyah Sîratuh wa Akhbâruh, (Riyadh: Dar al-Salam, $1428 \mathrm{H})$.

Shalih Fauzan, Min Masyâhir Mujaddidayn fî al-Islâm, (KSA, 1417H).

Ibn Taimiyyah, Majmû' Fatâwâ, (KSA: Majma' Malik Fahd, 1995). 